\title{
Metastatic Malignant Testicular Germ Cell Tumor
}

National Cancer Institute

\section{Source}

National Cancer Institute. Metastatic Malignant Testicular Germ Cell Tumor. NCI

Thesaurus. Code C25771.

A malignant germ cell tumor that arises from the testis and has spread to another anatomic site. 